\title{
First-principles study of electronic, atomic structures, phonon spectra and dielectric properties of calcium and cadmium apatites
}

\author{
A.P.Soroka, V.L.Karbovskiy, V.H.Kasianenko
}

\author{
G.V.Kurdyumov Institute for Metal Physics, National Academy of \\ Sciences of Ukraine, 36 Vernadsky blvd., $03142 \mathrm{Kiev}$, Ukraine
}

\section{Received November 20, 2014}

\begin{abstract}
Phonon densities of states, dielectric constants, the Born effective charges, interatomic force constants of stoichiometric apatites $\mathrm{Me}_{10}\left(\mathrm{PO}_{4}\right)_{6} \mathrm{X}_{2}$, where $\mathrm{Me}=\mathrm{Ca}$ or $\mathrm{Cd}$ and $\mathrm{X}=\mathrm{F}$, $\mathrm{Cl}, \mathrm{Br}, \mathrm{OH}$, were calculated in the framework of DFPT with pseudopotential approach and plane wave basis sets. Phonon densities of states of all investigated apatites were proven to have similar structures which consist of four bands, consistently with previously reported phonon spectra of $\mathrm{Ca}_{10}\left(\mathrm{PO}_{4}\right)_{6} \mathrm{~F}_{2}$ and $\mathrm{Ca}_{10}\left(\mathrm{PO}_{4}\right)_{6}(\mathrm{OH})_{2}$. Phonon frequencies for calcium apatites are well consistent with the experimental IR-absorption curves. We have established the effects of evolution in spatial charge distributions, electron energy structures of valence bands and band gaps for apatites of the series $\mathrm{Me}_{10}\left(\mathrm{PO}_{4}\right)_{6} \mathrm{X}_{2}$, where $\mathrm{Me}=\mathrm{Ca}$ or $\mathrm{Cd}$ and $\mathrm{X}=\mathrm{F}, \mathrm{Cl}$, $\mathrm{Br}, \mathrm{OH}$. Band gaps in the calcium apatites were correctly described in the framework of density functional theory. Lattice constants and bond lengths in apatites $\mathrm{Me}_{10}\left(\mathrm{PO}_{4}\right)_{6} \mathrm{X}_{2}$, where $\mathrm{Me}=\mathrm{Ca}$ or $\mathrm{Cd}$ and $\mathrm{X}=\mathrm{F}, \mathrm{Cl}, \mathrm{Br}, \mathrm{OH}$, were calculated in the framework of the density functional theory which are in a good concordance with the experimental observations. High stability of $\mathrm{PO}_{4}$-anions with respect to substitution of column ions in the apatite structure was found, which means the small variation in volumes of $\mathrm{PO}_{4}$ tetrahedra. We have calculated phonon dispersion curves for $\mathrm{Ca}_{10}\left(\mathrm{PO}_{4}\right)_{6} \mathrm{~F}_{2}$, and have shown that the speed of sound along the six-fold screw axis in $\mathrm{Ca}_{10}\left(\mathrm{PO}_{4}\right)_{6} \mathrm{~F}_{2}, \mathrm{Ca}_{10}\left(\mathrm{PO}_{4}\right)_{6} \mathrm{Cl}_{2}$, $\mathrm{Ca}_{10}\left(\mathrm{PO}_{4}\right)_{6}(\mathrm{OH})_{2}, \mathrm{Ca}_{10}\left(\mathrm{PO}_{4}\right)_{6} \mathrm{Br}_{2}$ was larger than that in the planes perpendicular to it.

Keywords: apatite, density functional theory, density functional perturbation theory, electronic structure, phonon structure, dielectric constants.
\end{abstract}

Фононные плотности состояний, диэлектрические постоянные, тензоры эффективных зарядов Борна, межатомные силовые постоянные стехиометрических апатитов $\mathrm{Me}_{10}\left(\mathrm{PO}_{4}\right)_{6} \mathrm{X}_{2}$, где $\mathrm{Me}=\mathrm{Ca}$ или $\mathrm{Cd}$ и $\mathrm{X}=\mathrm{F}, \mathrm{Cl}, \mathrm{Br}, \mathrm{OH}$, были рассчитаны в рамках теории возмущения функционала электронной плотности (DFPT), используя псевдопотенциальный метод и плоские волны в качестве базиса. Показано, что фононные плотности состояний всех исследованных апатитов имеют подобные структуры, которые состоят из четырех полос, что находится в согласии с ранее публикованными результатами по фононным спектрам $\mathrm{Ca}_{10}\left(\mathrm{PO}_{4}\right)_{6} \mathrm{~F}_{2}$ и $\mathrm{Ca}_{10}\left(\mathrm{PO}_{4}\right)_{6}(\mathrm{OH})_{2}$. Фононные частоты для апатитов кальция хорошо согласуются с экспериментальными кривыми ИК-поглощения. Установлены эффекты эволюции пространственного распределения заряда и энергии электронов валентных зон для апатитов серии $\mathrm{Me}_{10}\left(\mathrm{PO}_{4}\right)_{6} \mathrm{X}_{2}$, где $\mathrm{Me}=\mathrm{Ca}$ или $\mathrm{Cd}$ и $\mathrm{X}=\mathrm{F}, \mathrm{Cl}, \mathrm{Br}, \mathrm{OH}$. Ширины запрещенных зон апатитов кальция были правильно описаны в рамках теории функционала электронной плотности. В рамках теории функционала электронной плотности рассчитаны параметры решеток и длины связей апатитов $\mathrm{Me}_{10}\left(\mathrm{PO}_{4}\right)_{6} \mathrm{X}_{2}$, где $\mathrm{Me}=\mathrm{Ca}$ или $\mathrm{Cd}$ и $\mathrm{X}=\mathrm{F}, \mathrm{Cl}, \mathrm{Br}$, OH, которые находятся в хорошем соответствии с экспериментальными данными. Обнаружена высокая стабильность $\mathrm{PO}_{4}$ анионов по отношению $\mathrm{k}$ замещению анионов $X$ в структуре апатита, что означает небольшое изменение объемов тетраэдров $\mathrm{PO}_{4}$. Рассчитаны кривые дисперсии для фо- 
нонов в $\mathrm{Ca}_{10}\left(\mathrm{PO}_{4}\right)_{6} \mathrm{~F}_{2}$, и показано, что скорость звука вдоль винтовой оси шестого порядка в $\mathrm{Ca}_{10}\left(\mathrm{PO}_{4}\right)_{6} \mathrm{~F}_{2}, \mathrm{Ca}_{10}\left(\mathrm{PO}_{4}\right)_{6} \mathrm{Cl}_{2}, \mathrm{Ca}_{10}\left(\mathrm{PO}_{4}\right)_{6}(\mathrm{OH})_{2}, \mathrm{Ca}_{10}\left(\mathrm{PO}_{4}\right)_{6} \mathrm{Br}_{2}$ больше, чем в плоскостях, перпендикулярных к ней.

Фононні густини станів, діелектричні константи, тензори ефективних зарядів Борна, міжатомні силові константи стехіометричних апатитів $\mathrm{Me}_{10}\left(\mathrm{PO}_{4}\right)_{6} \mathrm{X}_{2}$, де $\mathrm{Me}=\mathrm{Ca}$ або $\mathrm{Cd}$ i $\mathrm{X}=\mathrm{F}, \mathrm{Cl}, \mathrm{Br}, \mathrm{OH}$, були розраховані в рамках теорії збурення функціоналу електронної густини (DFPT), використовуючи псевдопотенціальний метод і плоскі хвилі в якості базису. Показано, що фононні густини станів всіх досліджених апатитів мають подібні структури, які складаються з чотирьох смуг, що знаходиться у відповідності до раніше опублікуванних результів по фононним спектрам $\mathrm{Ca}_{10}\left(\mathrm{PO}_{4}\right)_{6} \mathrm{~F}_{2} \mathrm{i}$ $\mathrm{Ca}_{10}\left(\mathrm{PO}_{4}\right)_{6}(\mathrm{OH})_{2}$. Фононні частоти для апатитів кальцію добре узгоджуються з експериментальними кривими ІЧ-поглинання. Встановлено ефекти еволюції просторового розподілу заряду і енергії електронів валентних зон для апатитів серії $\mathrm{Me}_{10}\left(\mathrm{PO}_{4}\right)_{6} \mathrm{X}_{2}$, де $\mathrm{Me}$ $=\mathrm{Ca}$ або $\mathrm{Cd}$ i X $=\mathrm{F}, \mathrm{Cl}, \mathrm{Br}, \mathrm{OH}$. Ширини заборонених зон апатитів кальцію правильно описуються в рамках теорії функціонала електронної густини. У рамках теорії функціонала електронної густини розраховано параметри граток і довжини зв'язків апатитів $\mathrm{Me}_{10}\left(\mathrm{PO}_{4}\right)_{6} \mathrm{X}_{2}$, де $\mathrm{Me}=\mathrm{Ca}$ або $\mathrm{Cd}$ i $\mathrm{X}=\mathrm{F}, \mathrm{Cl}, \mathrm{Br}, \mathrm{OH}$, які знаходяться в добрій відповідності з експериментальними даними. Виявлена висока стабільність $\mathrm{PO}_{4}$-аніонів по відношенню до заміщення аніонів $X$ в структурі апатиту, що означає незначну зміну об'ємів $\mathrm{PO}_{4}$-тетраедрів. Розраховано криві дисперсії для фононів в $\mathrm{Ca}_{10}\left(\mathrm{PO}_{4}\right)_{6} \mathrm{~F}_{2}$, i показано, що швидкість звуку вздовж гвинтової осі шостого порядку в $\mathrm{Ca}_{10}\left(\mathrm{PO}_{4}\right)_{6} \mathrm{~F}_{2}$, $\mathrm{Ca}_{10}\left(\mathrm{PO}_{4}\right)_{6} \mathrm{Cl}_{2}, \mathrm{Ca}_{10}\left(\mathrm{PO}_{4}\right)_{6}(\mathrm{OH})_{2}, \mathrm{Ca}_{10}\left(\mathrm{PO}_{4}\right)_{6} \mathrm{Br}_{2}$ більша, ніж у площинах перпендикулярних до неї.

\section{Introduction}

Apatites compose is a class of compounds with general chemical formula $\mathrm{Me}_{10}\left(\mathrm{ZO}_{4}\right)_{6} \mathrm{X}_{2}$, where $\mathrm{Me}^{n+}, n=1-3 ; \mathrm{Z}^{\mathrm{m}+}$, $m=1-3 ; \mathrm{X}$ - electronegative element or hydroxyl group. They attract attention of researchers for a long time due to a wide range of their practical applications. Most often they are used as compatible with bone tissue artificial bioactive materials, moisture and alcohol sensors, matrices for radioactive waste, storage of environmentally harmful matter. Such a wide range of their practical applications stimulates search for the new apatite compounds with the desired properties. Because of the complexity of synthesis of apatites with the desired properties, ab initio quantum-mechanical calculations are the main tools for analysis of their electronic structure and properties.

Apatites mainly belong to $P 6_{3} / \mathrm{m}$ space group [1]. Therefore, calcium atoms can occupy two nonequivalent positions: $\mathrm{Ca}_{(1)}$ and $\mathrm{Ca}_{(2)}$. In certain cases depending on the synthesis conditions and apatite's constituents the apatite's symmetry may decrease to $P 6_{3}$ or $P 2_{1} / b[2,3]$. Space group $P 6_{3} / m$ implies the point group of $\mathrm{PO}_{4}$-tetrahedra being $C_{s}$, therefore, three nonequivalent positions for oxygen atoms exist $\left(\mathrm{O}_{(1)}, \mathrm{O}_{(2)}\right.$ and $\left.\mathrm{O}_{(3)}\right)$. Anions $X$ are located at high-symmetric positions $(0,0,0.25)$ and $(0,0,0.75)$. $\mathrm{OH}-$ groups in hydroxyapatites can display alteration of their orientations $(\mathrm{OH}-\mathrm{HO})$ when moving along six-fold screw axis. Such an effect locally destroys the $P 6_{3} / m$ symmetry leading to $P 2_{1} / b$. Apatites with hexagonal symmetry have more than 40 atoms per unit cell, and apatites with monoclinic symmetry have more than 80 ones. In addition, in both cases primitive cells volumes are sufficiently large. Therefore, only recently due to rapid increase in power of computers, the density functional theory have become feasible for the apatite compounds. Since calcium apatites were subjected to a number of first-principles calculations. Using pseudopotential approach within DFT, Calderin et al. [3] have analyzed the crystal and electronic structures of stoichiometric calcium hydroxy-, fluoro-, chloro- and oxyapatites. They found that there is no significant preference of monoclinic structure for hexagonal one due to very close energies per unit cell for the both structures. Based on theoretical results, they also showed that calcium hydroxyapatite can easily exchange $\mathrm{OH}$ groups with other negative charged ions, which is consistent with experimental observations. Later Calderin et al. [4] using classical shell model studied lattice dynamic and obtained theoretical IR-spectra for calcium hydroxyapatite. Semi-empirical model potential methods were applied by Corno et al. [5] and Pedone et al. [6] establishing the interpretation of the vibrational modes with phonon frequencies above $400 \mathrm{~cm}^{-1}$ in terms of internal vibrations of $\mathrm{PO}_{4}$ tetrahedra. In all these studies good agreement between the 
theoretical results and experiment was observed. Despite of the recent progress in semi-empirical approaches in computational studies of vibrational properties of calcium apatites, such methods have many technical problems caused by the crystals complexity, and limited classical shell models [4]. Such results strongly depend on the model potentials that have to be fitted to match the experimental data. Therefore, first-principles DFPT approaches are to be used for theoretical investigations of vibrational properties of the apatite compounds. In [7], the both experimental IR-spectroscopy and theoretical DFPT methods were used to investigate vibration spectra of calcium fluorand hydroxyapatites. Special focus was made on the study of dependencies of the IR-spectra broadening on temperature. In order to investigate inhomogeneous broadenings of the IR-spectra related to long-range electrostatic effects, the IR absorption spectra were obtained for the powders with different particle shapes (sphere, needle and plate), and subsequent interpolations of the IR-spectra to zero-temperature point were performed. It was shown that $v_{3}$ vibration mode for calcium hydroxyapatite is significantly affected by the long-range Coloumb interaction, such an influence on $v_{4}$ is weaker, and for $v_{1}$ LO-TO splitting is very small. Therefore, the linebroadening of $v_{1}$ mode in calcium hydroxyapatite was established to indicate on deviation from the crystallinity in calcium hydroxyapatite. In more recent work [8], dedicated to vibrational and electronic properties of calcium chlor-, fluor- and hydroxyapatite apatites PAW-method in the framework of DFPT was used. Electronic densitites of the states, phonon frequencies with and without taking into account long-range electrostatic effects, the Born effective charge tensors, dielectric and elastic constants were computed, and all obtained results were in a good agreement with the experiment. To sum up, electronic and vibrational properties of the most common calcium phosphate apatites $\left(\mathrm{Ca}_{10}\left(\mathrm{ZO}_{4}\right)_{6} \mathrm{~F}_{2}, \mathrm{Ca}_{10}\left(\mathrm{ZO}_{4}\right)_{6} \mathrm{OH}_{2}\right)$ are well investigated to date, however, those of $\mathrm{Ca}_{10}\left(\mathrm{PO}_{4}\right)_{6} \mathrm{Cl} \mathrm{l}_{2}$ and $\mathrm{Ca}_{10}\left(\mathrm{PO}_{4}\right)_{6} \mathrm{Br}_{2}$ as well as of cadmium apatites remain virtually unstudied.

\section{Computational procedure}

The main objective of this research was the first-principles theoretical calculations of electronic structures, phonon spectra and dielectric properties for compounds
$M e_{10}\left(\mathrm{PO}_{4}\right)_{6} \mathrm{X}_{2}$, where $\mathrm{Me}=\mathrm{Ca}$ or $\mathrm{Cd}$ and $\mathrm{X}=$ $\mathrm{F}, \mathrm{Cl}, \mathrm{Br}, \mathrm{OH}$. We used the pseudopotential approach with plane waves as a basis [9] and the frozen core approximation for solving problems of the density functional theory. The HGH (Hartwigsen-Goedecker-Hutter) scheme was used [10] for pseudo wavefunctions and pseudopotentials generations, and core orbitals $\mathrm{Ca} 3 s$ and $\mathrm{Ca} 3 p$ were considered as valence that is vitally necessary due to the large number of oxygen atoms, and significant electronic charge flow from calcium to oxygen. The calculations were performed thanks to ABINIT code, a common project of the Universite Catholique de Louvain, Corning Incorporated and other contributors (http://www.abinit.org).

The electronic structure calculations were performed within the DFT-LDA approach with the Teter-Pade parametrization of exchange-correlation potential. It is wellknown that LDA-functionals usually overbinds and underestimates bond lengths, and in the most cases GGA-functionals give better results. However, formalism of LDA is more straightforward, and the errors due to LDA preserve trends, therefore for the purpose of the study we have performed the calculations within the framework of the DFT-LDA. In the calculations of electronic structure and energetic we used 3-3-5 Monkhorst-Pack meshes centered at $\Gamma$-point and the kinetic energy cut-off parameter of 979.2 eV.

The density functional theory is the most common technique not only in the firstprinciples electronic structure calculations but also in ground state properties computations. Thereby, the extension of the density functional theory to density functional perturbation theory provides an access to calculations of physical quantities such as the frequency dependent dielectric tensor, the Born effective charges, phonon frequencies and their dispersion laws, interatomic force tensors (the Hessian matrices), elastic, compliant and piezoelectric tensors. All these characteristics are obtained by calculating the second order partial derivatives of the total energy with respect to individual atom shift along the particular direction (phonon perturbation), a constant external electric field and external mechanical stress [1113]. Derivatives of the first and the second types were used in the present work.

Calculations of the phonon spectra and interatomic force constants were carried out in the three following stages. 
I stage. The equilibrium positions of atoms in the unit cells were calculated, i.e. the structural geometries were relaxed until each component of forces, which act on individual atoms, become less than $4.12 \cdot 10^{-12} \mathrm{~N}$ and qeach stress tensor component become less than $8.84 \mathrm{MPa}$. The initial positions of atoms were taken according to experimental structure reported by [14]. The relaxations to such small forces are necessary for the calculations because requirement for derivative of the total energy with respect to an arbitrary atom displacement along the arbitrary direction equals to zero (i.e. force acting on each individual atom is equal to zero) is a prerequisite for the further calculation of the phonon perturbations. For this part of the calculation we used the following parameters that affect accuracy of the results within the framework of the density functional theory:

a) for exchange-correlation potential it was used the local density approximation with the Teter-Pade parameterization;

b) the kinetic energy cut-off parameter was taken large (979.2 eV);

c) the Brilouin zone sampling was $2-2-3$ centered at $\boldsymbol{\Gamma}$-point (4 nonequivalent k-points).

II stage. The calculation of wave functions using the atomic coordinates in the unit cells, which were obtained in the previous stage. At this stage we used very high convergence criteria, the self-consistent field calculation was performed until the energy difference between two successive iterations become less than $2.6 \cdot 10^{-15} \mathrm{eV}$. All the parameters that affect the accuracy of calculations were the same as in the first stage.

III stage. At this point, the calculations were performed basing on the electronic wave functions that were obtained in the second stage. The second order derivatives of the total energy were calculated using the procedure of the density functional perturbation theory (DFPT). The following perturbations were computed.

1. Two perturbations, caused by external electric field, directed along $x$ and $z$ axes, respectively [11]. The perturbations in the directions of $x$ and $y$ axes are equivalent due to the transverse symmetry of the crystals. The calculation of these perturbations is an integral part of the computation of phonon frequency at $\Gamma$-point because for dielectric material the interaction of transverse phonons with the longitudinal ones must be considered (LO-TO splitting).
2. Nineteen independent phonon perturbations (in the case of calcium and cadmium hydroxyapatites 28 independent phonon perturbation were computed, which is caused by decrease of the lattice space group symmetry of hydroxyapatites compared with chloro-, fluoro- or bromapatites). These phonon perturbations were used to calculate 126 phonon dispersion curves (in the case of calcium and cadmium hydroxyapatites there were 132 phonons totally). The parameters that affect the accuracy for this part of calculation were taken the same as for I and II stages. In all three stages we used fixed occupation numbers for valance electrons.

In order to calculate phonon frequencies of isolated $\mathrm{PO}_{4}$-tetrahedra we used significantly large cubic charged supercell of about $888 \AA^{3}$ volume. Kinetic energy cutoff parameter was larger than for apatites, and equaled to $1360 \mathrm{eV}$. The calculations were performed in three stages as for apatite compounds, except for electric field perturbations were not computed (LO-TO splitting did not occur in isolated molecules). Phonon modes were calculated only at $\boldsymbol{\Gamma}$-point with using varied occupation numbers of valence electrons in order to avoid problems with degenerate HOMO level.

\section{Results and discussion}

In most cases the apatite structure is characterized by six-fold screw axis and reflection planes which are perpendicular to it. Both of these symmetries specify for the apatite twelve symmetry transformations and space group $\mathrm{P}_{3} / \mathrm{m}$. It means that for calcium atom there are two nonequivalent positions $-\mathrm{Ca}_{(1)}$ and $\mathrm{Ca}_{(2)} \cdot \mathrm{Ca}_{(1)}$ atoms are located in the space between $\mathrm{PO}_{4}$-molecules at $(1 / 3,2 / 3 ; z),(2 / 3,1 / 3 ; z),(2 / 3,1 / 3 ; z$ $+1 / 2),(1 / 3,2 / 3 ; 1 / 2-z)$. They form nine bonds with oxygen atoms: three bonds $\mathrm{Ca}_{(1)}-\mathrm{O}_{(1)}$, three $\mathrm{Ca}_{(1)}-\mathrm{O}_{(2)}$ and three $\mathrm{Ca}_{(1)}-\mathrm{O}_{(3)}$. Calcium atoms of the second nonequivalent positions are located in the mirror planes that pass through the points $(0$, $0,0.25),(0,0,0.75)$, and are perpendicular to the sixth-fold screw axis. These atoms form triangles around the anions which are located at the sixth-fold screw axis (anions X). Anions $\mathrm{X}$ occupies the high-symmetry points $(0,0,0.25),(0,0,0.75)$.

The crystal structure and calculated electronic distribution in coordinate space for calcium chlorapatite with $P 6_{3} / m$ symmetry are presented in Fig. 1. 


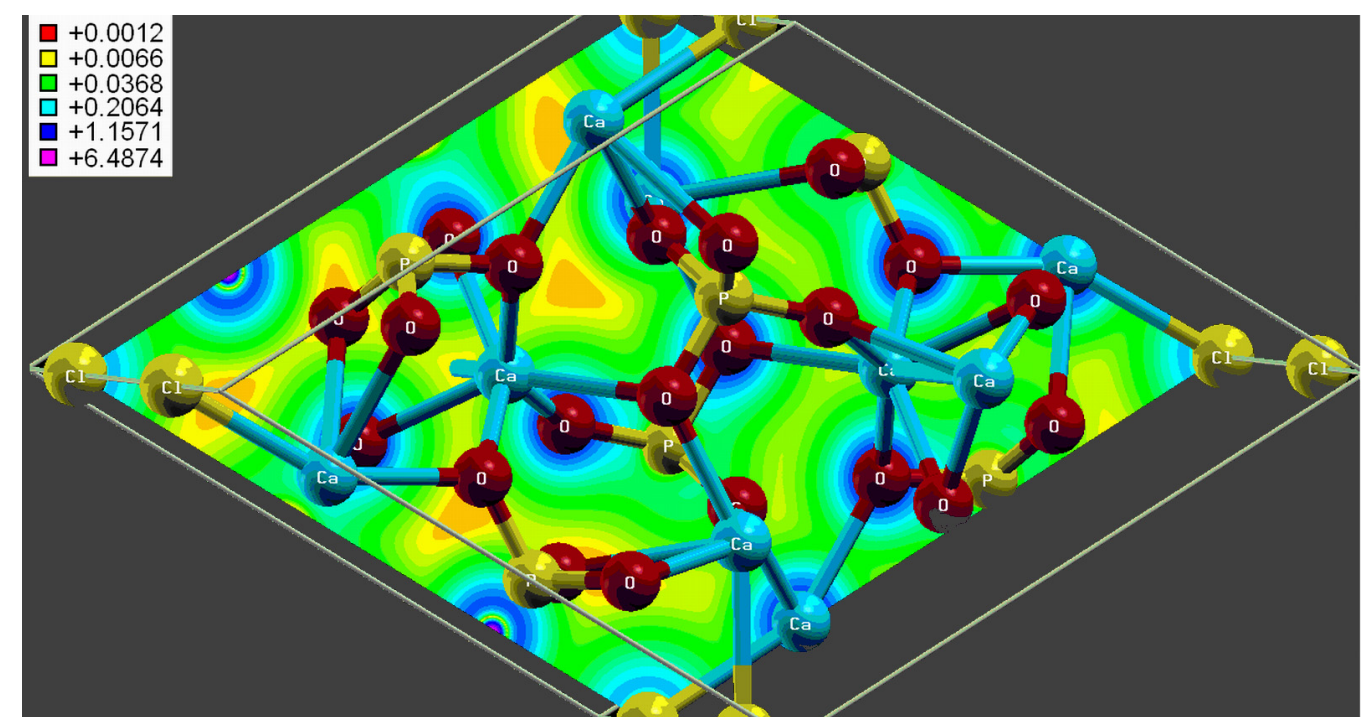

Fig. 1. Electronic charge distribution in $(0,0,1)$ plane that passes through $(0,0,1 / 4)$ point.

The distribution contains near-gap region, subvalence region as well as core $\mathrm{Ca}$ $3 p$ levels. The spatial distribution of $\mathrm{Ca} 3 p$ core electrons has sufficiently large extension, they are located at some distance from the nucleus. Figure 1 demonstrates that the wave function of $\mathrm{Ca} 3 p$ electrons has a node at some distance from the nucleus.

We would not submit the computed total densities of states because it was done in the earlier works, but would note some interesting points. In the earlier work [15], Ca $3 p$ states in calcium hydroxyapatite were established to fall in the valance region. According to our results this fact is also valid for calcium fluor-, chlor- and bromapatites. As it was shown in $[8,15]$, for $\mathrm{Ca}_{10}\left(\mathrm{PO}_{4}\right)_{6} \mathrm{~F}_{2}$ the bottom of conduction band is formed by Ca $3 d$ states, and we showed that it is also valid for calcium fluor-, chlor- and bromapatite. Calcium bromoapatite have "tail" in the near-gap region which significantly reduced the band gap, compared with other calcium apatites. It is formed by $\mathrm{Br} 4 p$ states which substantially increase dispersion in the near-gap region. According to [16] the dispersion in the valence band top reduced in the order $\mathrm{Ca}_{10}\left(\mathrm{PO}_{4}\right)_{6} \mathrm{~F}_{2}, \mathrm{Ca}_{10}\left(\mathrm{PO}_{4}\right)_{6}(\mathrm{OH})_{2}, \mathrm{Ca}_{10}\left(\mathrm{PO}_{4}\right)_{6} \mathrm{Cl}_{2}$, $\mathrm{Ca}_{10}\left(\mathrm{PO}_{4}\right)_{6} \mathrm{Br}_{2}$, and our results confirm this statement. Calculated LDA-gaps are presented in Table 1 . We can see that calculated band gaps reduce in the series

$$
\begin{aligned}
& \mathrm{Ca}_{10}\left(\mathrm{PO}_{4}\right)_{6} \mathrm{~F}_{2} \rightarrow \mathrm{Ca}_{10}\left(\mathrm{PO}_{4}\right)_{6} \mathrm{Cl}_{2} \rightarrow \\
& \mathrm{Ca}_{10}\left(\mathrm{PO}_{4}\right)_{6}(\mathrm{OH})_{2} \rightarrow \mathrm{Ca}_{10}\left(\mathrm{PO}_{4}\right)_{6} \mathrm{Br}_{2}
\end{aligned}
$$

for calcium apatites, and in the series
Table 1. Band gaps in investigated apatites

\begin{tabular}{|c|c|c|}
\hline Band gap & $\begin{array}{c}\Delta E \text { (HOMO- } \\
\text { LUMO), eV } \\
\text { (calculation) }\end{array}$ & $\begin{array}{c}\text { Band gap, eV } \\
\text { (experiment) }\end{array}$ \\
\hline $\mathrm{Ca}_{10}\left(\mathrm{PO}_{4}\right)_{6} \mathrm{~F}_{2}$ & 5.6 & $5.9[17]$ \\
$\mathrm{Ca}_{10}\left(\mathrm{PO}_{4}\right)_{6} \mathrm{Cl}_{2}$ & 5.4 & $5.6[17]$ \\
$\mathrm{Ca}_{10}\left(\mathrm{PO}_{4}\right)_{6}(\mathrm{OH})_{2}$ & 5.3 & $5.4[17]$ \\
$\mathrm{Ca}_{10}\left(\mathrm{PO}_{4}\right)_{6} \mathrm{Br}_{2}$ & 4.0 & - \\
$\mathrm{Cd}_{10}\left(\mathrm{PO}_{4}\right)_{6} \mathrm{~F}_{2}$ & 2.6 & - \\
$\mathrm{Cd}_{10}\left(\mathrm{PO}_{4}\right)_{6}(\mathrm{OH})_{2}$ & 2.5 & - \\
$\mathrm{Cd}_{10}\left(\mathrm{PO}_{4}\right)_{6} \mathrm{Cl} 2$ & 2.3 & - \\
$\mathrm{Cd}_{10}\left(\mathrm{PO}_{4}\right)_{6} \mathrm{Br}_{2}$ & 2.3 & - \\
\hline
\end{tabular}

$$
\begin{gathered}
\mathrm{Cd}_{10}\left(\mathrm{PO}_{4}\right)_{6} \mathrm{~F}_{2} \rightarrow \mathrm{Cd}_{10}\left(\mathrm{PO}_{4}\right)_{6} \mathrm{OH}_{2} \\
\mathrm{Cd}_{10}\left(\mathrm{PO}_{4}\right)_{6} \mathrm{Cl}_{2} \rightarrow \mathrm{Ca}_{10}\left(\mathrm{PO}_{4}\right)_{6} \mathrm{Br}_{2}
\end{gathered}
$$

for cadmium ones. Therefore, for all investigated apatites, with the exception of calcium hydroxyapatite, the band gap reduces with the $\mathrm{X}$-ion electronegativity reduction. For $\mathrm{Ca}_{10}\left(\mathrm{PO}_{4}\right)_{6}(\mathrm{OH})_{2} \mathrm{H} 1 s$ states appear in the bottom of conduction band (the "tail" in total DOS curves), and reduce the band gap compared to $\mathrm{Ca}_{10}\left(\mathrm{PO}_{4}\right)_{6} \mathrm{~F}_{2}$. Following the comparison of the calculated band gaps for $\mathrm{Ca}_{10}\left(\mathrm{PO}_{4}\right)_{6} \mathrm{~F}_{2}, \mathrm{Ca}_{10}\left(\mathrm{PO}_{4}\right)_{6} \mathrm{Cl}_{2}, \mathrm{Ca}_{10}\left(\mathrm{PO}_{4}\right)_{6}(\mathrm{OH})_{2}$ with the experimental results [17] we reveal a very good concordance, LDA-gaps are little smaller than the experimental counterparts (within the limits of 0.3). Those band gaps underestimations are normal for the DFT calculations. It is interesting to compare the calculated band gaps for 
Table 2. Interatomic force constants for $\mathrm{P}-\mathrm{O}_{(1)}, \mathrm{P}-\mathrm{O}_{(2)}, \mathrm{P}-\mathrm{O}_{(3)}, \mathrm{P}-\mathrm{Ca}(2), \mathrm{Ca}(1)-\mathrm{O}, \mathrm{Ca}(2)-\mathrm{X}, \mathrm{Ca}(2)-\mathrm{O}_{(3)}$ bonds in compounds $\mathrm{Ca}_{10}\left(\mathrm{PO}_{4}\right)_{6} \mathrm{X}_{2}$, where $\mathrm{X}=\mathrm{F}$, OH, $\mathrm{Cl}$ or $\mathrm{Br}$

\begin{tabular}{|c|c|c|c|c|}
\hline $\begin{array}{l}\text { Interatomic force } \\
\text { constants, } \mathrm{kN} \cdot \mathrm{m}^{-1}\end{array}$ & $\mathrm{Ca}_{10}\left(\mathrm{PO}_{4}\right)_{6} \mathrm{~F}_{2}$ & $\mathrm{Ca}_{10}\left(\mathrm{PO}_{4}\right)_{6}(\mathrm{OH})_{2}$ & $\mathrm{Ca}_{10}\left(\mathrm{PO}_{4}\right)_{6} \mathrm{Cl}_{2}$ & $\mathrm{Ca}_{10}\left(\mathrm{PO}_{4}\right)_{6} \mathrm{Br}_{2}$ \\
\hline$\left[P-\mathrm{O}_{(1)}\right]_{X X}$ & -0.506 & -0.497 & -0.490 & -0.481 \\
\hline$\left[\mathrm{P}-\mathrm{O}_{(1)}\right]_{y y}$ & -0.098 & -0.098 & -0.097 & -0.095 \\
\hline$\left[\mathrm{P}-\mathrm{O}_{(1)}\right]_{z z}$ & -0.100 & -0.098 & -0.100 & -0.100 \\
\hline$\left[\mathrm{P}-\mathrm{O}_{(2)}\right]_{X X}$ & -0.458 & -0.457 & -0.439 & -0.423 \\
\hline$\left[\mathrm{P}-\mathrm{O}_{(2)}\right]_{y y}$ & -0.103 & -0.101 & -0.101 & -0.098 \\
\hline$\left[\mathrm{P}-\mathrm{O}_{(2)}\right]_{z z}$ & -0.103 & -0.101 & -0.101 & -0.100 \\
\hline$\left[\mathrm{P}-\mathrm{O}_{(3)}\right]_{X X}$ & -0.469 & -0.469 & -0.475 & -0.472 \\
\hline$\left[\mathrm{P}-\mathrm{O}_{(3)}\right]_{y y}$ & -0.097 & -0.097 & -0.095 & -0.095 \\
\hline$\left[\mathrm{P}-\mathrm{O}_{(3)}\right]_{z z}$ & -0.104 & -0.103 & -0.103 & -0.098 \\
\hline$\left[\mathrm{P}-\mathrm{Ca}_{(2)}\right]_{x x}$ & -0.064 & -0.062 & -0.059 & -0.058 \\
\hline$\left[\mathrm{P}-\mathrm{Ca}_{(2)}\right]_{y y}$ & 0.011 & 0.011 & 0.013 & 0.013 \\
\hline$\left[\mathrm{P}-\mathrm{Ca} a_{(2)}\right]_{z z}$ & 0.045 & 0.044 & 0.044 & 0.044 \\
\hline$\left[\mathrm{Ca}(1)-\mathrm{O}_{(1)}\right]_{X x}$ & -0.022 & -0.016 & -0.070 & -0.065 \\
\hline$\left[\mathrm{Ca}(1)-\mathrm{O}_{(1)}\right]_{y y}$ & -0.012 & -0.012 & -0.009 & -0.008 \\
\hline$\left[\mathrm{Ca}(1)-\mathrm{O}_{(1)}\right]_{z z}$ & -0.011 & -0.011 & -0.009 & -0.008 \\
\hline$\left[\mathrm{Ca}(2)-\mathrm{X}_{(1)}\right]_{x x}$ & -0.031 & -0.037 & -0.067 & -0.067 \\
\hline$\left[\mathrm{Ca}(2)-\mathrm{X}_{(1)}\right]_{y y}$ & -0.011 & -0.011 & -0.002 & 0.002 \\
\hline$\left[\mathrm{Ca}(2)-\mathrm{X}_{(1)}\right]_{z z}$ & -0.009 & -0.011 & 0.002 & -0.002 \\
\hline$\left[\mathrm{Ca}(2)-\mathrm{O}_{(3)}\right]_{X x}$ & -0.025 & -0.026 & -0.037 & -0.033 \\
\hline$\left[\mathrm{Ca}(2)-\mathrm{O}_{(3)}\right]_{y y}$ & -0.008 & -0.009 & -0.006 & -0.008 \\
\hline$\left[\mathrm{Ca}(2)-\mathrm{O}_{(3)}\right]_{\mathrm{zz}}$ & -0.008 & -0.008 & -0.011 & -0.008 \\
\hline
\end{tabular}

$\mathrm{Ca}_{10}\left(\mathrm{PO}_{4}\right)_{6}(\mathrm{OH})_{2}$ with other ones, calculated within the framework of DFT, in the earlier works. Matsunaga et al. reported of $5.4 \mathrm{eV}$, Demkov et al. $-5.3 \mathrm{eV}$ and results of Rulis et al. $-4.5 \mathrm{eV}$. Compared the previously reported and our results as well as the experimental data we can conclude that using plane waves basis sets within the framework of DFT give an excellent agreement with the experiment [8, 15, 17] but using liner combination of atomic orbitals leads to significantly larger band gap underestimation by the DFT-calculations. Another interesting discreapency is related to the band gap for $\mathrm{Ca}_{10}\left(\mathrm{PO}_{4}\right)_{6} \mathrm{Br}_{2}$. Rulis et al. have reported the calculated band gap for $\mathrm{Ca}_{10}\left(\mathrm{PO}_{4}\right)_{6} \mathrm{Br}_{2}$ being larger than for $\mathrm{Ca}_{10}\left(\mathrm{PO}_{4}\right)_{6}(\mathrm{OH})_{2}$ in contrast to our results, and this is the main difference in the bang gaps for $\mathrm{Ca}_{10}\left(\mathrm{PO}_{4}\right)_{6} \mathrm{~F}_{2}, \mathrm{Ca}_{10}\left(\mathrm{PO}_{4}\right)_{6} \mathrm{Cl}_{2}$, $\mathrm{Ca}_{10}\left(\mathrm{PO}_{4}\right)_{6}(\mathrm{OH})_{2}, \mathrm{Ca}_{10}\left(\mathrm{PO}_{4}\right)_{6} \mathrm{Br}_{2}$ of Rulis's results comparing with our ones. The experiment should be performed to clarify the

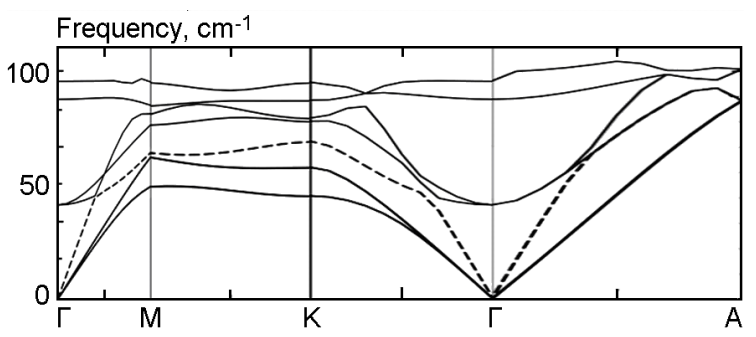

Fig. 2. Dispersion curves for three acoustic phonons and first four optical phonons. (-) are the dispersion relations for two transverse acoustic phonons, $(--)$ is the dispersion curve for the longitudinal phonon and (-) are four branches for the optical phonons along the $\mathbf{\Gamma}-\mathbf{M}, \mathbf{M}-\mathbf{K}, \mathbf{K}-\boldsymbol{\Gamma}$ and $\boldsymbol{\Gamma}-\mathbf{A}$ lines of the reciprocal lattice for calcium fluoroapatite.

problem. Comparing the calculated band gaps of calcium apatites with those of cadmium ones we can conclude that the calcium apatites have much larger band gaps. Small band gaps widths for the cadmium apatites are caused by arising $\mathrm{Cd} 5 p$ states in the 
Table 3. Interatomic force constants for $\mathrm{P}-\mathrm{O}_{(1)}, \mathrm{P}-\mathrm{O}_{(2)}, \mathrm{P}-\mathrm{O}_{(3)}$ bonds in compounds $\mathrm{Cd}_{10}\left(\mathrm{PO}_{4}\right)_{6} \mathrm{X}_{2}$, where $\mathrm{X}=\mathrm{F}, \mathrm{OH}, \mathrm{Cl}$ or $\mathrm{Br}$

\begin{tabular}{||c|c|c|c|c||}
\hline $\begin{array}{c}\text { Interatomic force } \\
\text { constants, } \mathrm{kN} \cdot \mathrm{m}^{-1}\end{array}$ & $\mathrm{Cd}_{10}\left(\mathrm{PO}_{4}\right)_{6} \mathrm{~F}_{2}$ & $\mathrm{Cd}_{10}\left(\mathrm{PO}_{4}\right)_{6}(\mathrm{OH})_{2}$ & $\mathrm{Cd}_{10}\left(\mathrm{PO}_{4}\right)_{6} \mathrm{Cl}_{2}$ & $\mathrm{Cd}_{10}\left(\mathrm{PO}_{4}\right)_{6} \mathrm{Br}_{2}$ \\
\hline$\left[\mathrm{P}-\mathrm{O}_{(1)}\right]_{X x}$ & -0.406 & -0.464 & -0.480 & -0.701 \\
{$\left[\mathrm{P}-\mathrm{O}_{(1)}\right]_{y y}$} & -0.125 & -0.093 & -0.076 & -0.064 \\
{$\left[\mathrm{P}-\mathrm{O}_{(1)}\right]_{z z}$} & -0.092 & -0.083 & -0.093 & -0.078 \\
{$\left[\mathrm{P}-\mathrm{O}_{(2)}\right]_{x x}$} & -0.391 & -0.452. & -0.355 & -0.598 \\
{$\left[\mathrm{P}-\mathrm{O}_{(2)}\right]_{y y}$} & -0.095 & -0.093 & -0.093 & -0.061 \\
{$\left[\mathrm{P}-\mathrm{O}_{(2)}\right]_{z z}$} & -0.090 & -0.079 & -0.090 & -0.084 \\
{$\left[\mathrm{P}-\mathrm{O}_{(3)}\right]_{x x}$} & -0.488 & -0.433 & -0.469 & -0.548 \\
{$\left[\mathrm{P}-\mathrm{O}_{(3)}\right]_{y y}$} & -0.084 & -0.081 & -0.093 & -0.084 \\
{$\left[\mathrm{P}-\mathrm{O}_{(3)}\right]_{z z}$} & -0.083 & -0.086 & -0.083 & - \\
\hline
\end{tabular}

bottom of the conduction bands. However, this fact requires experimental verification, maybe it is due to well-known problem of the band gap underestimation by the DFT calculations.

The results of the first-principle calculations of the phonon dispersion curves for $\mathrm{Ca}_{10}\left(\mathrm{PO}_{4}\right)_{6} \mathrm{~F}_{2}$ in the framework of DFPT are presented in Fig. 2.

Only three acoustic phonons dispersion curves and first four optical ones are depicted in the figure. The remaining $119 \mathrm{op}-$ tical phonon branches are not represented in order to avoid overloading of the figure. The points $\Gamma(0.0,0.0,0.0), \mathbf{M}(0.25,0.25,0)$, $\mathrm{K}(0.5,0.0,0.0), \mathbf{A}(0.0,0.0,0.5)$ in the reciprocal lattice are critical in all hexagonal structures. Since the angle at $\Gamma$-point for transverse acoustic vibrations is larger than that for longitudinal vibration, we can conclude that the speed of sound along the screw axis is larger than in xy plane. Such rule is valid for all investigated calcium apatites. Therefore, the speed of sound along c-axis for $\mathrm{Ca}_{10}\left(\mathrm{PO}_{4}\right)_{6} \mathrm{~F}_{2}, \mathrm{Ca}_{10}\left(\mathrm{PO}_{4}\right)_{6} \mathrm{Cl}_{2}$, $\mathrm{Ca}_{10}\left(\mathrm{PO}_{4}\right)_{6}(\mathrm{OH})_{2}, \quad \mathrm{Ca}_{10}\left(\mathrm{PO}_{4}\right)_{6} \mathrm{Br}_{2}$ is larger than in the planes perpendicular to it. The dispersion curves of transverse acoustic and optical oscillations are superimposed while passing along $\mathbf{\Gamma}-\mathbf{A}$ line that is determined by the crystal symmetry of the apatites.

First we have calculated the phonon densities of states without long-range Coulomb interaction [18]. Calculated phonon density of the states within such an approximation for the apatites $\mathrm{Me}_{10}\left(\mathrm{PO}_{4}\right)_{6} \mathrm{X}_{2}$, where $\mathrm{Me}$ is $\mathrm{Ca}$ or $\mathrm{Cd}$ and $\mathrm{X}=\mathrm{F}, \mathrm{OH}, \mathrm{Cl}$ or $\mathrm{Br}$, are depicted in Fig. 3. Phonon frequencies at $\boldsymbol{\Gamma}$ point which correspond to stretching or bending modes of two $\mathrm{A}$ and $\mathrm{B}$ atoms can be estimated as

$$
\omega(\Gamma) \approx \sqrt{\frac{k}{m_{A B}}},
$$

where $k$ - is one of the diagonal component of the interatomic force interaction tensor (Tables 2 and 3 ) and $m_{A B}$ is reduced mass of A and B atoms which can be calculated as $m_{A B}=m_{A} \cdot m_{B} / m_{A}+m_{B}$.

The graphs clearly demonstrate that the phonon density of the states for apatites $\mathrm{Me}_{10}\left(\mathrm{PO}_{4}\right)_{6} \mathrm{X}_{2}$, where $\mathrm{Me}$ is $\mathrm{Ca}$ or $\mathrm{Cd}$ and $\mathrm{X}=\mathrm{F}, \mathrm{OH}$, or $\mathrm{Cl}$ and $\mathrm{Ca}_{10}\left(\mathrm{PO}_{4}\right)_{6} \mathrm{Br}_{2}$ have pronounced band character with the different lengths of individual bands. The first band which contains most of the vibrational modes is localized in the frequency range from 0 to $370 \mathrm{~cm}^{-1}$ for the calcium apatites and from 0 to $330 \mathrm{~cm}^{-1}$ for the cadmium ones. The second band falls in the frequency range from $380 \mathrm{~cm}^{-1}$ to $500 \mathrm{~cm}^{-1}$, and the position of this band on the frequency scale was different for different types of the apatites. The third band is localized in the range from $500 \mathrm{~cm}^{-1}$ to $600 \mathrm{~cm}^{-1}$ and the fourth one from $800 \mathrm{~cm}^{-1}$ to $1150 \mathrm{~cm}^{-1}$. For each calcium apatite in the fourth band an intense peak is observed. The position of the peak depends on the type of the $c$-axis anion. For $\mathrm{Ca}_{10}\left(\mathrm{PO}_{4}\right)_{6} \mathrm{~F}_{2}$ its position is $956 \mathrm{~cm}^{-1}$, for $\mathrm{Ca}_{10}\left(\mathrm{PO}_{4}\right)_{6}(\mathrm{OH})_{2}-952 \mathrm{~cm}^{-1}$, for $\mathrm{Ca}_{10}\left(\mathrm{PO}_{4}\right)_{6} \mathrm{Cl}_{2}-908 \mathrm{~cm}^{-1}$, and for $\mathrm{Ca}_{10}\left(\mathrm{PO}_{4}\right)_{6} \mathrm{Br}_{2}-938 \mathrm{~cm}^{-1}$.

According to [17], $\mathrm{PO}_{4}^{3-}$ tetrahedron has four vibrational modes $v_{1}=980 \mathrm{~cm}^{-1}, v_{2}=$ $363 \mathrm{~cm}^{-1}, v_{3}=1082 \mathrm{~cm}^{-1}$ and $v_{4}=515 \mathrm{~cm}^{-1}$. Comparing these data with the calculated phonon density of the states (Fig. 3) for apatites $\mathrm{Me}_{10}\left(\mathrm{PO}_{4}\right)_{6} \mathrm{X}_{2}$, where $\mathrm{Me}=\mathrm{Ca}$ or 


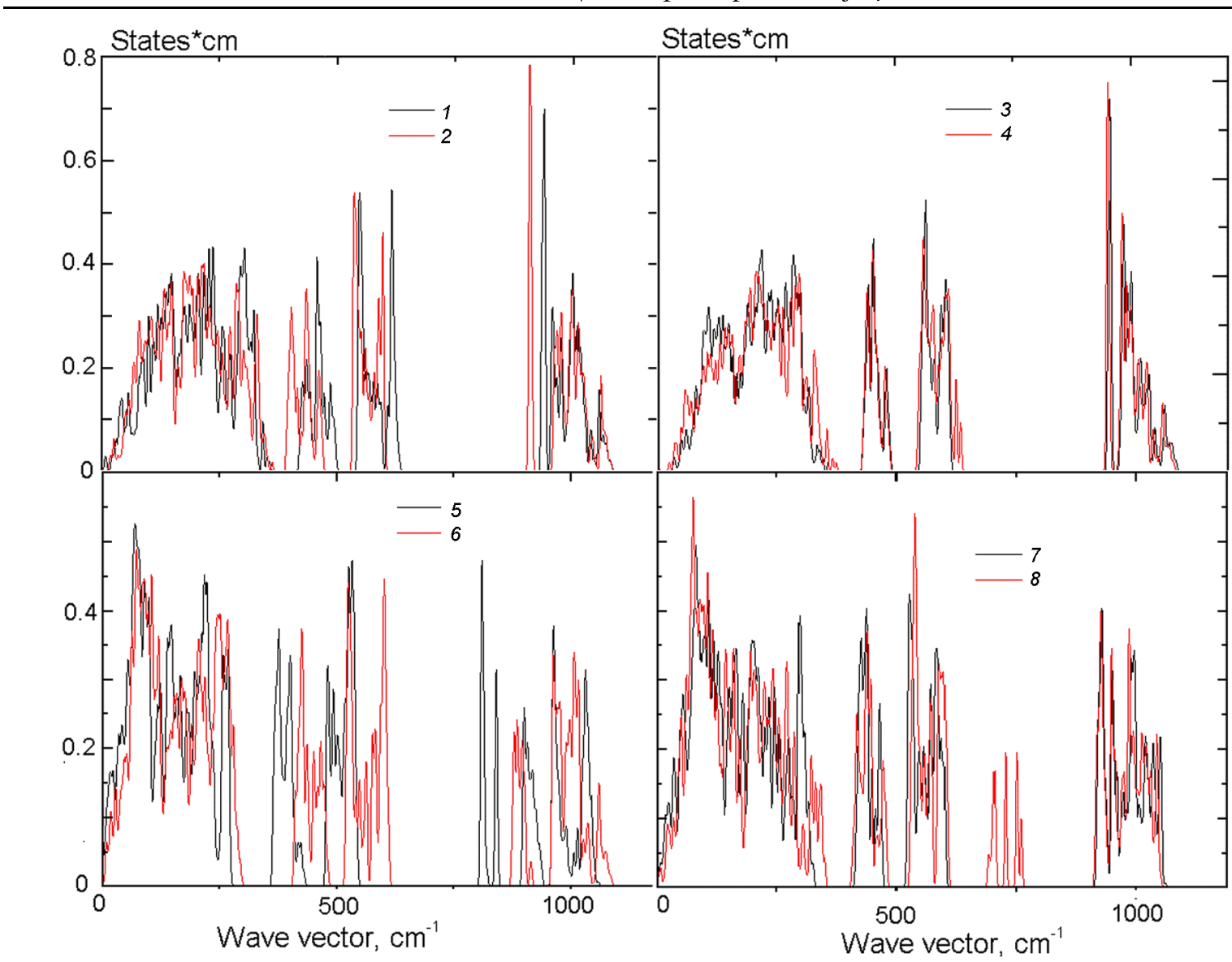

Fig. 3. Phonon density of states for the following apatites. $1-\mathrm{Ca}_{10}\left(\mathrm{PO}_{4}\right)_{6} \mathrm{Br}_{2}, 2-\mathrm{Ca}_{10}\left(\mathrm{PO}_{4}\right)_{6} \mathrm{Cl}_{2}$, $3-\mathrm{Ca}_{10}\left(\mathrm{PO}_{4}\right)_{6} \mathrm{~F}_{2}, 4-4 \mathrm{Ca}_{10}\left(\mathrm{PO}_{4}\right)_{6}(\mathrm{OH})_{2}, 5-\mathrm{Cd}_{10}\left(\mathrm{PO}_{4}\right)_{6} \mathrm{Br}_{2}, 6-\mathrm{Cd}_{10}\left(\mathrm{PO}_{4}\right)_{6} \mathrm{Cl}_{2}, 7-$ $\mathrm{Cd}_{10}\left(\mathrm{PO}_{4}\right)_{6} \mathrm{~F}_{2}, 8-\mathrm{Cd}_{10}\left(\mathrm{PO}_{4}\right)_{6} \mathrm{OH}_{2}$.

$\mathrm{Cd}$, and $\mathrm{X}=\mathrm{F}, \mathrm{Cl}, \mathrm{Br}, \mathrm{OH}$, we conclude that in the apatites $v_{1}$ and $v_{3}$ modes form the fourth band of the states phonon density in the range of wave vectors from the $900 \mathrm{~cm}^{-1}$ to $1150 \mathrm{~cm}^{-1}$. These modes mainly correspond to stretching vibrations of phosphorus and oxygen atoms around their common center of mass. Modes $v_{4}$ and $v_{2}$ form bands with the lower energies, namely the third and second bands of the states phonon densities, respectively, which are localized in the frequency regions from $500 \mathrm{~cm}^{-1}$ to $600 \mathrm{~cm}^{-1}$, and from $380 \mathrm{~cm}^{-1}$ to $500 \mathrm{~cm}^{-1}$. These bands mainly correspond to the stretching modes for $\mathrm{O}-\mathrm{O}$ bond as well as bending modes for $\mathrm{P}-\mathrm{O}$ bond.

The first, most "massive" band of the phonon density of the states for apatites $\mathrm{Me}_{10}\left(\mathrm{PO}_{4}\right)_{6} \mathrm{X}_{2}$, where $\mathrm{Me}=\mathrm{Ca}$ or $\mathrm{Cd}$ and $\mathrm{X}=$ $\mathrm{F}, \mathrm{Cl}, \mathrm{Br}, \mathrm{OH}$, which is localized in the frequency range from 0 to $370 \mathrm{~cm}^{-1}$, consists of three parts. The stretching and bending modes for $\mathrm{Ca}_{(2)}-\mathrm{X}$ as well as the stretching and bending modes for $\mathrm{Ca}_{(2)}-\mathrm{P}$ mainly contribute to the most "energetic" sub-band of the first band which ranges from 250 to $370 \mathrm{~cm}^{-1}$. The substitution in calcium fluorapatite of fluorine atoms for chlorine, bromine or hydroxyl group increases the reduced mass of $\mathrm{Ca}_{(2)}-\mathrm{X}$ bonds. The interatomic force constants for these atoms are also increased by the substitutions, thereby the energy of these oscillations remains almost unchanged. The second part of the first bands, which occupies the frequency range from 150 to $250 \mathrm{~cm}^{-1}$, is formed by stretching and bending vibrations of the $\mathrm{Ca}_{(1)}-\mathrm{O}_{(1)}, \quad \mathrm{Ca}_{(1)}-\mathrm{O}_{(2)}, \quad \mathrm{Ca}_{(1)}-\mathrm{O}_{(3)}$. Finally, the third sub-band of the first band of the phonon density of the states is formed by all other bonds including three acoustic phonons.

$\mathrm{O}-\mathrm{H}$ bending vibrations occur at frequencies 630 and $501 \mathrm{~cm}^{-1}$ for the calcium and cadmium hydroxyapatite, respectively. According to the experimental IR-absorption data the $\mathrm{OH}$-bending mode for calcium hydroxyapatite is at $625 \mathrm{~cm}^{-1}$, so we have excellent agreement between the experimental and calculated results even without includ- 


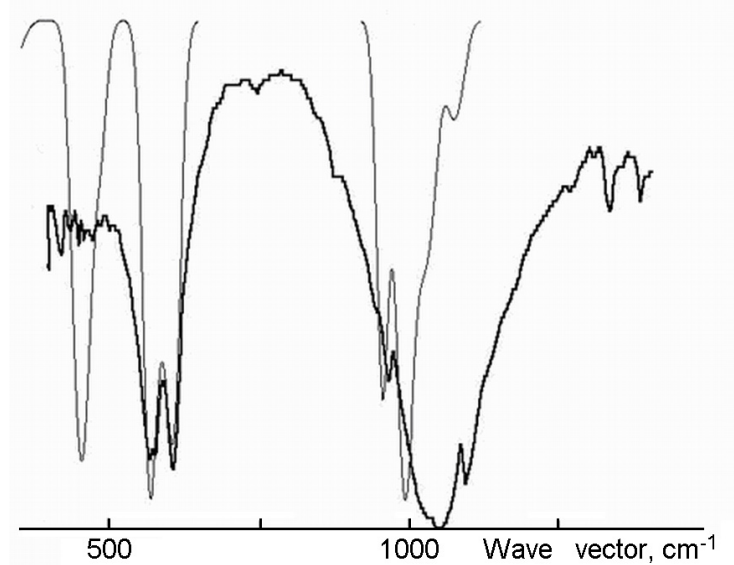

Fig. 4. Experimental IR-absorption spectrum (solid line) and theoretical phonon densities of the states calculated within the framework of DFPT (thin line) for calcium fluoroapatite.

ing the long-range electrostatic interaction. It is interesting to compare our results with other theoretical works. In Demkov et al. work PAW-method within the framework of the DFT-GGA was used and overestimation of the $\mathrm{OH}$ bending mode was much larger (11 \%). In contrast to the calcium hydroxyapatite, for cadmium hydroxyapatite (sixth curve in Fig. 3), these vibrations fell into the energy gap between the second and the third bands and, therefore, a single sharp peak is formed in the curve of the phonon density of the states.

The phonon frequencies, which correspond to the stretching vibrations of oxygen and hydrogen atoms for the calcium and cadmium hydroxyapatites are not depicted in Fig. 3 and according to the IR spectroscopy data [17] the frequency for calcium hydroxyapatite equals to $3573 \mathrm{~cm}^{-1}$. On the other hand, calculation in the framework of the DFPT shows that these oscillations correspond to two phonon branches centered at 3499 and $3528 \mathrm{~cm}^{-1}$, respectively. We have obtained two frequencies for the stretching modes of $\mathrm{O}-\mathrm{H}$ bonds because for hydroxyapatite simulation $P 6_{3}$ symmetry is used instead of $P 6_{3} / m$. Thus, a good agreement between the theoretical and experimental frequencies is observed for the stretching vibrations of oxygen and hydrogen atoms around their common center of mass (less than $2 \%$ deviation from the experiment). In [8], almost the same deviation was reported, but overestimation of the $\mathrm{OH}$ stretching mode occurred, in contrast to our observation of underestimation. Therefore, for the both stretching and bending mode
Table 4. Experimental and calculated bond lengths of $\mathrm{PO}_{4}$-tetrahedra in $\mathrm{Ca}_{10}\left(\mathrm{PO}_{4}\right)_{6} \mathrm{~F}_{2}$

\begin{tabular}{||c|c|c|c||}
\hline $\begin{array}{c}\text { Bond/ } \\
\text { bond } \\
\text { length }\end{array}$ & $\begin{array}{c}\text { Experiment, } \\
\AA\end{array}$ & $\begin{array}{c}\text { Calculation } \\
\text { (HGH- } \\
\text { scheme), } \AA\end{array}$ & $\begin{array}{c}\text { Deviation } \\
\text { from } \\
\text { experiment, } \\
\%\end{array}$ \\
\hline $\mathrm{P}-\mathrm{O}_{(1)}$ & 1.5477 & 1.5449 & 0.2 \\
$\mathrm{P}_{-} \mathrm{O}_{(2)}$ & 1.5490 & 1.5591 & 0.7 \\
$\mathrm{P}_{-} \mathrm{O}_{(3)}$ & 1.5317 & 1.5518 & 1.3 \\
$\mathrm{O}_{(1)}-\mathrm{O}_{(2)}$ & 2.5525 & 2.5597 & 0.3 \\
$\mathrm{O}_{(1)}-\mathrm{O}_{(3)}$ & 2.5420 & 2.5562 & 0.6 \\
$\mathrm{O}_{(2)}-\mathrm{O}_{(3)}$ & 2.4950 & 2.5168 & 0.9 \\
$\mathrm{O}_{(3)}-\mathrm{O}_{(3)}$ & 2.4588 & 2.4955 & 1.5 \\
\hline \hline
\end{tabular}

we obtained the frequencies underestimation, and in [8] the frequencies overestimation was observed. The fact seems to be strange, because using LDA-functionals usually leads to higher phonon frequencies than GGA ones. The difference obviously comes from different methods, we used the pseudopotential method with HGH-scheme, and [8] used PAW-method. For cadmium hydroxyapatite $\mathrm{OH}$-streching vibrations take place at lower frequencies (3472 and $3508 \mathrm{~cm}^{-1}$ ). The Bader charge calculation have given effective charges for oxygen and hydrogen ions in the calcium hydroxyapatite -1.266 and +0.470 electron charge, respectively. Oxygen and hydrogen ionic charges for the cadmium hydroxyapatite obtained by the Bader analysis of atoms in molecules are equal to -1.151 and +0.433 electron charge, respectively. Therefore, the substitution of calcium atoms for cadmium ones is accompanied by decrease of concentration of the electron density at $\mathrm{OH}$ groups and, on the other hand, the length of $\mathrm{OH}$ bond remains almost unchanged. These two factors lead to the decrease of interatomic force constants for the $\mathrm{O}-\mathrm{H}$ bond. Nevertheless, this fact still requires experimental verification.

Figure 4 displays comparison of theoretical phonon density of the states with the experimental IR-absorption spectrum for calcium fluoroapatite. In this case we used the Gaussian smearing of $20 \mathrm{~cm}^{-1}$, in contrast to Fig. 4, where smearing is not used. We note a good agreement between experiment and calculation. Mode at $\sim 425 \mathrm{~cm}^{-1}$ is likely not active in IR spectroscopy, and for the most "energetic" band (from 900 to $1150 \mathrm{~cm}^{-1}$ ) it is observed some theoretical phonon frequencies underestimation. Since this part of the band corresponds to the 
Table 5. Experimental and calculated lattice constants for $\mathrm{Me}_{10}\left(\mathrm{PO}_{4}\right)_{6} \mathrm{X}_{2}$, where $\mathrm{Me}=\mathrm{Ca}$ or $\mathrm{Cd}$, $\mathrm{X}=\mathrm{F}, \mathrm{Cl}, \mathrm{Br}, \mathrm{OH}$

\begin{tabular}{|c|c|c|c|c|c|c|c|c||}
\hline \multirow{2}{*}{$\begin{array}{c}\text { Lattice constants/ } \\
\text { compound }\end{array}$} & \multicolumn{4}{|c|}{ Calculation } & \multicolumn{4}{c||}{ Experiment [14] } \\
\cline { 2 - 9 } & $a, \AA$ & $c, \AA$ & $c / a$ & $V, \AA^{3}$ & $a, \AA$ & $c, \AA$ & $c / a$ & $V, \AA^{3}$ \\
\hline $\mathrm{Ca}_{10}\left(\mathrm{PO}_{4}\right)_{6} \mathrm{~F}_{2}$ & 9.36 & 6.86 & 0.733 & 520.48 & 9.39 & 6.88 & 0.733 & 525.35 \\
$\mathrm{Ca}_{10}\left(\mathrm{PO}_{4}\right)_{6}(\mathrm{OH})_{2}$ & 9.34 & 6.86 & 0.735 & 518.26 & 9.42 & 6.88 & 0.730 & 528.71 \\
$\mathrm{Ca}_{10}\left(\mathrm{PO}_{4}\right)_{6} \mathrm{Cl}_{2}$ & 9.65 & 6.83 & 0.708 & 550.82 & 9.62 & 6.76 & 0.703 & 541.79 \\
$\mathrm{Ca}_{10}\left(\mathrm{PO}_{4}\right)_{6} \mathrm{Br}_{2}$ & 9.73 & 6.80 & 0.699 & 557.53 & 9.76 & 6.74 & 0.691 & 556.02 \\
$\mathrm{Cd}_{10}\left(\mathrm{PO}_{4}\right)_{6} \mathrm{~F}_{2}$ & 9.19 & 6.63 & 0.752 & 495.54 & 9.30 & 6.63 & 0.713 & 496.60 \\
$\mathrm{Cd}_{10}\left(\mathrm{PO}_{4}\right)_{6}(\mathrm{OH})_{2}$ & 9.41 & 6.69 & 0.711 & 513.02 & 9.33 & 6.66 & 0.714 & 502.07 \\
$\mathrm{Cd}_{10}\left(\mathrm{PO}_{4}\right)_{6} \mathrm{Cl}_{2}$ & 9.55 & 6.52 & 0.679 & 520.38 & 9.67 & 6.50 & 0.672 & 526.38 \\
$\mathrm{Cd}_{10}\left(\mathrm{PO}_{4}\right)_{6} \mathrm{Br}_{2}$ & 9.55 & 6.75 & 0.708 & 532.02 & 8.46 & 6.45 & 0.762 & 399.79 \\
\hline
\end{tabular}

stretching and bending modes of $\mathrm{P}-\mathrm{O}$ bonds and structural relaxation using the pseudopotential method with the HGHscheme a little overestimates the lengths of P-O bonds within the limits of $1.3 \%$ (Table 4), theoretically calculated interatomic force constants for P-O interaction are underestimated. Hence, calculated frequencies that related to $\mathrm{P}-\mathrm{O}$ oscillations are a little lower than the experimental values.

The experimental and theoretically calculated lattice constants for apatites $\mathrm{Me}_{10}\left(\mathrm{PO}_{4}\right)_{6} \mathrm{X}_{2}$, where $\mathrm{M}=\mathrm{Ca}$ or $\mathrm{Cd}$ and $\mathrm{X}=$ $\mathrm{F}, \mathrm{Cl}, \mathrm{OH}, \mathrm{Br}$ are presented in Table 5 .

Criterion for obtaining the equilibrium lattice parameters and atomic positions in the cells was the fact that each of the component of forces that acts on each individual atom becomes less than $4.12 \cdot 10^{-12} \mathrm{~N}$, and each component of the stress tensor which acts on the cell as a whole becomes less than $8.84 \cdot 10^{6} \mathrm{~Pa}$. The general trend of the unit cell parameters underestimation (up to $3 \%$ ) by the calculations with LDAfunctionals in this case was not confirmed. For all investigated apatites, except for cadmium bromoapatite, the deviations from the experimental lattice constants are less than $1.5 \%$, and the calculated lattice constants are larger than the experimental ones for some compounds and for others are less. We note that for the calcium apatites the trends for a and c lattice parameters are correct, except for a lattice constant in $\mathrm{Ca}_{10}\left(\mathrm{PO}_{4}\right)_{6}(\mathrm{OH})_{2}$ compared to that in $\mathrm{Ca}_{10}\left(\mathrm{PO}_{4}\right)_{6} \mathrm{~F}_{2}$. The huge difference between the calculated and experimental data was established for the cadmium bromoapatite (more than $1 \AA$ deviation for a parameter and $0.3 \AA-$ for $c$ parameter). This deviation is a consequence of nonmonototic be- haviour of the lattice volume. Indeed, the replacement of $\mathrm{F}$ by $\mathrm{Br}$ in $\mathrm{Cd}_{10}\left(\mathrm{PO}_{4}\right)_{6} \mathrm{~F}_{2}$ decreases the unit cell volume, while the ionic radius of $F$ ion is much smaller than $B r$. Therefore, the decrease of the unit cell volume by such a substitution is anomalous. Calculation of the unit cell parameters for $\mathrm{Cd}_{10}\left(\mathrm{PO}_{4}\right)_{6} \mathrm{Br}_{2}$ does not detect the effect mentioned above, and gives the lattice constants for $\mathrm{Cd}_{10}\left(\mathrm{PO}_{4}\right)_{6} \mathrm{Br}_{2}$ which are larger than for $\mathrm{Cd}_{10}\left(\mathrm{PO}_{4}\right)_{6} \mathrm{~F}_{2}$. Putting the different initial positions of atoms in the unit cell does not resolve the problem, the structure always have fallen into the local minimum of energy which provides to large deviation of the calculated lattice constants for $\mathrm{Cd}_{10}\left(\mathrm{PO}_{4}\right)_{6} \mathrm{Br}_{2}$ from the experimental values. Therefore, such anomalous "structure compression" for $\mathrm{Cd}_{10}\left(\mathrm{PO}_{4}\right)_{6} \mathrm{Br}_{2}$ were not correctly reproduced by the calculations in the framework of DFT (or, may be, it is a typographical error in [14]).

In small external electric field the components of the external electric field $E$ can be written as $\varepsilon_{\alpha \beta}=\delta_{\alpha \beta}+4 \pi \cdot \chi_{\alpha \beta}$, where $\chi_{\alpha \beta}=R_{\alpha} / E_{\beta}, E$ is the external electric field, $P$ is polarization, and $\alpha$ and $\beta$ - one of the axes $x, y$ or $z$. The results of the first-principles calculations of dielectric tensor components are listed in Table 6.

The off-diagonal components of the tensors ( $x y, x z, y z, y x, z x, z y$ components) are close to zero, and the components $\varepsilon_{x x}$ and $\varepsilon_{\text {yy }}$ are equal due to the transverse crystal symmetry. $\varepsilon^{\infty}-$ is the tensor related to electronic component of the dielectric tensor, i.e. without relaxation of atoms under applying the constant external electric field. On the other hand, these components are the components of the dielectric tensors at frequencies above $3600 \mathrm{~cm}^{-1}$ when in the 
Table 6. Components of the dielectric tensor for investigated compounds

\begin{tabular}{||c|c|c|c|c|cc||}
\hline $\begin{array}{c}\text { Dielectric tensor } \\
\text { components }\end{array}$ & $\varepsilon_{x x}^{\infty}$ & $\varepsilon_{y y}^{\infty}$ & $\varepsilon_{z z}^{\infty}$ & $\varepsilon_{x x}^{0}$ & epsilonBB & $\varepsilon_{z y}^{0}$ \\
\hline $\mathrm{Ca}_{10}\left(\mathrm{PO}_{4}\right)_{6} \mathrm{~F}_{2}$ & 3.12 & 3.12 & 3.11 & 10.06 & 10.06 & 7.95 \\
$\mathrm{Ca}_{10}\left(\mathrm{PO}_{4}\right)_{6}(\mathrm{OH})_{2}$ & 3.19 & 3.19 & 3.14 & 11.45 & 11.45 & 7.77 \\
$\mathrm{Ca}_{10}\left(\mathrm{PO}_{4}\right)_{6} \mathrm{Cl}_{2}$ & 3.19 & 3.19 & 3.11 & 12.62 & 12.62 & 7.83 \\
$\mathrm{Ca}_{10}\left(\mathrm{PO}_{4}\right)_{6} \mathrm{Br}_{2}$ & 3.31 & 3.31 & 3.09 & 14.98 & 14.98 & 8.03 \\
$\mathrm{Cd}_{10}\left(\mathrm{PO}_{4}\right)_{6} \mathrm{~F}_{2}$ & 4.08 & 4.08 & 4.12 & - & - & - \\
$\mathrm{Cd}_{10}\left(\mathrm{PO}_{4}\right)_{6}(\mathrm{OH})_{2}$ & 4.39 & 4.39 & 4.49 & - & - & - \\
$\mathrm{Cd}_{10}\left(\mathrm{PO}_{4}\right)_{6} \mathrm{Cl}$ & 4.02 & 4.02 & 4.20 & - & - & - \\
$\mathrm{Cd}_{10}\left(\mathrm{PO}_{4}\right)_{6} \mathrm{Br}_{2}$ & 4.52 & 4.52 & 4.67 & - & - & - \\
\hline
\end{tabular}

Table 7. Diagonal components of the Born effective charge tensors for apatites $\mathrm{Me}_{10}\left(\mathrm{PO}_{4}\right)_{6} \mathrm{X}_{2}$, where $\mathrm{Me}=\mathrm{Ca}$ or $\mathrm{Cd}$ and $\mathrm{X}=\mathrm{F}, \mathrm{Cl}, \mathrm{Br}, \mathrm{OH}$

\begin{tabular}{|c|c|c|c|c|c|c|c|c|c|c|c|c||}
\hline $\begin{array}{c}\text { Components of } \\
\text { Born effective } \\
\text { charge tensors }\end{array}$ & $\mathrm{Me}_{(1) x x} \mathrm{Me}_{(1) y y}$ & $\mathrm{Me}_{(1) z z}$ & $\mathrm{Me}_{(2) x x}$ & $\mathrm{Me}_{(2) y y}$ & $\mathrm{Me}_{(2) z z}$ & $\mathrm{P}_{x x}$ & $\mathrm{P}_{y y}$ & $\mathrm{P}_{z z}$ & $\mathrm{X}_{x x}$ & $\mathrm{X}_{y y}$ & $\mathrm{X}_{z z}$ \\
\hline $\mathrm{Ca}_{10}\left(\mathrm{PO}_{4}\right)_{6} \mathrm{~F}_{2}$ & 2.39 & 2.39 & 2.67 & 2.47 & 2.47 & 2.34 & 3.27 & 3.27 & 3.15 & -1.57 & -1.57 & -0.74 \\
$\mathrm{Ca}_{10}\left(\mathrm{PO}_{4}\right)_{6}(\mathrm{OH})_{2}$ & 2.43 & 2.43 & 2.65 & 2.43 & 2.43 & 2.34 & 3.31 & 3.31 & 3.19 & -1.37 & -1.37 & -0.91 \\
$\mathrm{Ca}_{10}\left(\mathrm{PO}_{4}\right)_{6} \mathrm{Cl}_{2}$ & 2.45 & 2.45 & 2.68 & 2.46 & 2.46 & 2.39 & 3.35 & 3.35 & 3.23 & -1.47 & -1.47 & -1.50 \\
$\mathrm{Ca}_{10}\left(\mathrm{PO}_{4}\right)_{6} \mathrm{Br}_{2}$ & 2.48 & 2.48 & 2.72 & 2.45 & 2.45 & 2.43 & 3.38 & 3.38 & 3.27 & -1.37 & -1.37 & -2.30 \\
$\mathrm{Cd}_{10}\left(\mathrm{PO}_{4}\right)_{6} \mathrm{~F}_{2}$ & 2.61 & 2.61 & 2.96 & 2.64 & 2.64 & 2.99 & 3.46 & 3.46 & 3.43 & -1.61 & -1.61 & -0.54 \\
$\mathrm{Cd}_{10}\left(\mathrm{PO}_{4}\right)_{6}(\mathrm{OH})_{2}$ & 2.63 & 2.63 & 3.11 & 2.60 & 2.60 & 3.03 & 3.52 & 3.52 & 3.44 & -1.49 & -1.49 & -1.05 \\
$\mathrm{Cd}_{10}\left(\mathrm{PO}_{4}\right)_{6} \mathrm{Cl}_{2}$ & 2.68 & 2.68 & 3.24 & 2.58 & 2.58 & 3.13 & 3.57 & 3.57 & 3.50 & -1.45 & -1.45 & -1.16 \\
$\mathrm{Cd}_{10}\left(\mathrm{PO}_{4}\right)_{6} \mathrm{Br}_{2}$ & 2.58 & 2.58 & 2.88 & 2.32 & 2.32 & 2.63 & 3.80 & 3.80 & 3.50 & -0.57 & -0.57 & -1.57 \\
\hline
\end{tabular}

presence of an external electric field the atomic arrangement does not have time to rebuild. Tensors $\varepsilon^{\infty}$ have small deviations from diagonality, which significantly increase with substitution calcium by cadmium in the apatite structure. The deviation also increases in the series of

$$
\begin{gathered}
\mathrm{Me}_{10}\left(\mathrm{PO}_{4}\right)_{6} \mathrm{~F}_{2} \rightarrow \mathrm{Me}_{10}\left(\mathrm{PO}_{4}\right)_{6} \mathrm{OH}_{2} \rightarrow \\
\mathrm{Me}_{10}\left(\mathrm{PO}_{4}\right)_{6} \mathrm{Cl}_{2} \rightarrow \mathrm{Me}_{10}\left(\mathrm{PO}_{4}\right)_{6} \mathrm{Br}_{2}
\end{gathered}
$$

(i.e. with the decrease of X-ion electronegativity) for the calcium apatites as well as for cadmium ones, except for $\mathrm{Cd}_{10}\left(\mathrm{PO}_{4}\right)_{6} \mathrm{Br}_{2}$. However, for the calcium apatites $\varepsilon^{\infty}{ }_{x x}$ is larger than $\varepsilon^{\infty}{ }_{z z}$ in contrary to the cadmium apatites. Also we note that $\varepsilon^{\infty}$ component for the cadmium apatites are much larger than the ones for the calcium ones (more than $30 \%$ ), this is caused by much smaller calculated band gaps for the calcium apatites with respect to the cadmium ones. It is interesting to compare these calculated values with other DFPT results of $\varepsilon^{\infty}$ and ex-

Functional materials, 22, 1, 2015 perimental observations. We observe some dielectric constants overestimation both by our calculation as well as by [7] in comparison with experimental observations. However, the tendencies that $\varepsilon^{\infty}{ }_{x x}$ is larger than $\varepsilon_{z z}^{\infty}$ for $\mathrm{Ca}_{10}\left(\mathrm{PO}_{4}\right)_{6} \mathrm{~F}_{2}$ and $\mathrm{Ca}_{10}\left(\mathrm{PO}_{4}\right)_{6}(\mathrm{OH})_{2}$, as well as the fact that the anisotropy of dielectric tensor for $\mathrm{Ca}_{10}\left(\mathrm{PO}_{4}\right)_{6} \mathrm{~F}_{2}$ is lower than the one for $\mathrm{Ca}_{10}\left(\mathrm{PO}_{4}\right)_{6}(\mathrm{OH})_{2}$, correctly reproduced by DFPT-calculation.

The extent of anisotropy of $\varepsilon^{0}$ tensor also increases in series

$$
\begin{gathered}
\mathrm{Ca}_{10}\left(\mathrm{PO}_{4}\right)_{6} \mathrm{~F}_{2} \rightarrow \mathrm{Ca}_{10}\left(\mathrm{PO}_{4}\right)_{6}(\mathrm{OH})_{2} \rightarrow \\
\mathrm{Ca}_{10}\left(\mathrm{PO}_{4}\right)_{6} \mathrm{Cl}_{2} \rightarrow \mathrm{Ca}_{10}\left(\mathrm{PO}_{4}\right)_{6} \mathrm{Br}_{2} .
\end{gathered}
$$

For calcium apatite $\varepsilon_{x x}^{0}$ is greater than $\varepsilon_{z z^{0}}^{0}$ In addition, the extent of $\varepsilon^{0}$-tensors anisotropy is greater than the ones of $\varepsilon^{\infty}$.

Change of dipole moment generally can be written as

$$
\Delta \bar{P}=\frac{1}{\Omega_{Q_{0}}} \int_{\bar{r}} \delta(\bar{r}) d^{3} \bar{r},
$$


Table 8. Diagonal components of the Born effective charge tensors for oxygen atoms

\begin{tabular}{|c|c|c|c|c|c|c|c|c|c||}
\hline $\begin{array}{c}\text { Components of } \\
\text { Born effective } \\
\text { charge tensors }\end{array}$ & $\mathrm{O}_{(1) x x}$ & $\mathrm{O}_{(1) y y}$ & $\mathrm{O}_{(1) z z}$ & $\mathrm{O}_{(2) x x}$ & $\mathrm{O}_{(2) y y}$ & $\mathrm{O}_{(2) z z}$ & $\mathrm{O}_{(3) x x}$ & $\mathrm{O}_{(3) y y}$ & $\mathrm{O}_{(3) z z}$ \\
\hline $\mathrm{Ca}_{10}\left(\mathrm{PO}_{4}\right)_{6} \mathrm{~F}_{2}$ & -2.06 & -2.06 & -1.36 & -1.93 & -1.93 & -1.25 & -1.46 & -1.46 & -2.20 \\
$\mathrm{Ca}_{10}\left(\mathrm{PO}_{4}\right)_{6}(\mathrm{OH})_{2}$ & -1.97 & -1.97 & -1.35 & -1.97 & -1.97 & -1.24 & -1.48 & -1.48 & -2.20 \\
$\mathrm{Ca}_{10}\left(\mathrm{PO}_{4}\right)_{6} \mathrm{Cl}_{2}$ & -1.98 & -1.98 & -1.32 & -2.03 & -2.03 & -1.23 & -1.47 & -1.47 & -2.18 \\
$\mathrm{Ca}_{10}\left(\mathrm{PO}_{4}\right)_{6} \mathrm{Br}_{2}$ & -1.98 & -1.98 & -1.28 & -2.07 & -2.07 & -1.20 & -1.49 & -1.49 & -2.13 \\
$\mathrm{Cd}_{10}\left(\mathrm{PO}_{4}\right)_{6} \mathrm{~F}_{2}$ & -2.16 & -2.16 & -1.31 & -2.19 & -2.19 & -1.31 & -1.48 & -1.48 & -2.80 \\
$\mathrm{Cd}_{10}\left(\mathrm{PO}_{4}\right)_{6}(\mathrm{OH})_{2}$ & -2.11 & -2.11 & -1.29 & -2.22 & -2.22 & -1.30 & -1.49 & -1.49 & -2.82 \\
$\mathrm{Cd}_{10}\left(\mathrm{PO}_{4}\right)_{6} \mathrm{Cl}_{2}$ & -2.09 & -2.09 & -1.23 & -2.28 & -2.28 & -1.28 & -1.54 & -1.54 & -2.88 \\
$\mathrm{Cd}_{10}\left(\mathrm{PO}_{4}\right)_{6} \mathrm{Br}_{2}$ & -2.18 & -2.18 & -1.42 & -2.32 & -2.32 & -1.32 & -1.57 & -1.57 & -2.40 \\
\hline
\end{tabular}

where $\delta(\bar{r})$ is the change in charge density, caused, for example, by external electric field and $\Omega_{0}$ is the volume of the unit cell. The charge density is defined as the sum of electronic and nuclear densities, the latter is equal to the sum of delta functions multiplied by the nuclei charges. Then, the Born effective charge of $v$ atom is defined as $Z_{v, \alpha \beta}=\frac{\Omega_{0}(\Delta \bar{P})_{\alpha}}{e} u_{\beta}$, where $u_{\beta}-$ is atom displacement along the direction $u_{\beta}$. Thus, the effective Born charges tensor determines how the $\beta$-component of polarization changes when $v$-atom is displaced along $\alpha$-axis.

Diagonal components of the Born effective charges tensors for compounds $\mathrm{Me}_{10}\left(\mathrm{PO}_{4}\right)_{6} \mathrm{X}_{2}$, where $\mathrm{Me}$ is $\mathrm{Ca}$ or $\mathrm{Cd}$, and $\mathrm{X}=\mathrm{F}, \mathrm{OH}, \mathrm{Cl}$ or $\mathrm{Br}$ are presented in Tables 7 and 8.

The interatomic force constants in cartesian coordinate system, calculated in the framework of DFPT, are listed in Tables 2 and 3 . The first vector $(x)$ of the frame of reference is directed along the line containing two interacting atoms (along the bond). The second vector $(y)$ is taken perpendicular to the first one, and the force arising by displacement of atoms along the bond line. The third basis vector $(z)$ is taken perpendicular to the first and the second ones. Thus, the first basis vector is longitudinal, and the second and third basis vectors are transversal. Negative values for the most of diagonal components of the force tensors ( $x x, y y$ and $z z$ components) mean that the force that emerged by displacement of an atom along the particular direction have the direction opposite to the displacement.

The interaction of phosphorus-oxygen is very strong and the longitudinal component of the interatomic force tensors ranged from 0.423 to $0.506 \mathrm{kN} \cdot \mathrm{m}^{-1}$. The transverse components of these interactions are much smaller than the longitudinal ones (in five times), it means "the directivity" of the force interaction along $\mathrm{P}-\mathrm{O}$ bond. The offdiagonal components of the tensors are very small in comparison with the diagonal ones, which also points out the covalence nature of interaction in the $\mathrm{P}-\mathrm{O}$ bonds.

The interaction of phosphorus atom with the nearest oxygen environment changes only slightly when hydroxyl group is substituted for fluorine, chlorine or bromine ions. It means that the phonon frequencies that are related to $\mathrm{P}-\mathrm{O}$ vibrations remain almost unchanged by substitution in X-position (Fig. 3). However, the tendency of slight reduction of the longitudinal component of the interatomic tensor force tensors with the decrease of $\mathrm{X}$-anion electronegativity is established (it is more pronounced for the first and second nonequivalent oxygen atoms). Earlier, it was noted in [7] for $\mathrm{Ca}_{10}\left(\mathrm{PO}_{4}\right)_{6} \mathrm{~F}_{2}, \mathrm{Ca}_{10}\left(\mathrm{PO}_{4}\right)_{6} \mathrm{OH}_{2}$ and was assigned to the volume cell decrease. Therefore, we confirm this assertion, and generalized it to $\mathrm{Ca}_{10}\left(\mathrm{PO}_{4}\right)_{6} \mathrm{~F}_{2}, \mathrm{Ca}_{10}\left(\mathrm{PO}_{4}\right)_{6} \mathrm{OH}_{2}$ as well to the cadmium apatites. In spite of the fact that phosphorus is surrounded by oxygen atoms which should prevent interaction $\mathrm{P}-\mathrm{Ca}_{(2)}$, the interaction was proven to be quite strong (the longitudinal component ranged from 0.058 to $0.064 \mathrm{kN} \cdot \mathrm{m}^{-1}$ and decreases with the decrease of $\mathrm{X}$-anion electronegativity). The transverse components of the tensors are also significantly less than the longitudinal ones, similar to the phosphorus-oxygen bond. This obviously points out the covalent nature of phosphorus-calcium bond and directivity of the interactions in the bond direction. Interest- 
Table 9. Comparison of vibrational modes of $\mathrm{PO}_{4}$-tetrahedron calculated in the framework of DFPT with experimental values

\begin{tabular}{|c|c|c|c|c|c|c||}
\hline $\begin{array}{c}\text { Scheme for } \\
\text { pseudopotential }\end{array}$ & Ionic charge & $\begin{array}{c}\text { P-O bond } \\
\text { length, }\end{array}$ & $v_{1}, \mathrm{~cm}^{-1}$ & $v_{2}, \mathrm{~cm}^{-1}$ & $v_{3}, \mathrm{~cm}^{-1}$ & $v_{4}, \mathrm{~cm}^{-1}$ \\
\hline $\begin{array}{c}\text { Experiment } \\
\text { HGH }\end{array}$ & -3.00 & - & 980 & 363 & 1082 & 515 \\
HGH & 0 & 1.5181 & 922 & 161 & 1032 & 298 \\
HGH & -1.00 & 1.5270 & 920 & 235 & 999 & 363 \\
HGH & -2.00 & 1.5391 & 904 & 295 & 941 & 417 \\
HGH & -2.54 & 1.5407 & 895 & 280 & 953 & 403 \\
\hline
\end{tabular}

ingly, that oxygen atom of the neighboring oxygen tetrahedron is only slightly further from phosphorus atom than from calcium one (by $0.1 \div 0.2 \AA$ ), however IFCs (interatomic force constants) of $\mathrm{P}-\mathrm{O}$ (adjacent tetrahedron) are much smaller (about 6 times) than that for $\mathrm{P}-\mathrm{Ca}(2)$ bonds. Thus, the interaction of $\mathrm{P}-\mathrm{O}$ (adjacent tetrahedron) is weak.

The longitudinal interatomic force constants of $\mathrm{Ca}_{(1)}-\mathrm{O}$ bonds for calcium fluoroand hydroxyapatite are rather small $(-0.022$ and $-0.016 \mathrm{kN} \cdot \mathrm{m}^{-1}$, respectively). The transverse components of the interatomic force tensor turned out to be not much less than longitudinal ones, and equal to -0.012 and $-0.012 \mathrm{kN} \cdot \mathrm{m}^{-1}$. Thus, for calcium fluoro- and hydroxyapatites $\mathrm{Ca}_{(1)}-\mathrm{O}_{(1)}$ interaction is weak, and the bond is ionic. The reverse picture is observed for calcium chloro- and bromoapatites, longitudinal components of the interatomic force constants for $\mathrm{Ca}_{(1)}-\mathrm{O}_{(1)}$ are much larger in comparison with the ones for fluoro- and hydroxyapatites $\left(-0.070\right.$ and $-0.065 \mathrm{kN} \cdot \mathrm{m}^{-1}$, respectively). In addition, the transverse components of the tensors are much smaller than the longitudinal ones, i.e. the interaction nature is more covalent than for the calcium hydroxyapatite and fluoroapatite.

The strength of $\mathrm{Ca}(2)-\mathrm{X}$ bond increased in the series

$$
\begin{gathered}
\mathrm{Ca}_{10}\left(\mathrm{PO}_{4}\right)_{6} \mathrm{~F}_{2} \rightarrow \mathrm{Ca}_{10}\left(\mathrm{PO}_{4}\right)_{6}(\mathrm{OH})_{2} \rightarrow \\
\mathrm{Ca}_{10}\left(\mathrm{PO}_{4}\right)_{6} \mathrm{Cl}_{2} \rightarrow \mathrm{Ca}_{10}\left(\mathrm{PO}_{4}\right)_{6} \mathrm{Br}_{2} .
\end{gathered}
$$

It means that $\mathrm{Ca}_{(2)}-\mathrm{X}$ bond becomes more covalent in the above mentioned order. The transverse components of the interatomic force tensors of these interactions for $\mathrm{Ca}_{10}\left(\mathrm{PO}_{4}\right)_{6} \mathrm{~F}_{2}$ and $\mathrm{Ca}_{10}\left(\mathrm{PO}_{4}\right)_{6}(\mathrm{OH})_{2}$ are less about three times than the longitudinal ones, i.e. the bonds have partially ionic and partially covalent nature. The replacement of $c$-axis anion by $\mathrm{Cl}$ or $\mathrm{Br}$ ions leads to the drastic decrease of the transverse components, while the longitudinal ones increase, which also points out an increase of the covalent constituent of $\mathrm{Ca}_{(2)}-\mathrm{X}$ interactions.

Analyzing the strength in $\mathrm{Ca}_{(2)}-\mathrm{O}_{(3)}$ bonds we can conclude that the longitudinal component of the interatomic force constants increases in the series

$$
\begin{gathered}
\mathrm{Ca}_{10}\left(\mathrm{PO}_{4}\right)_{6} \mathrm{~F}_{2} \rightarrow \mathrm{Ca}_{10}\left(\mathrm{PO}_{4}\right)_{6}(\mathrm{OH})_{2} \rightarrow \\
\mathrm{Ca}_{10}\left(\mathrm{PO}_{4}\right)_{6} \mathrm{Br}_{2} \rightarrow \mathrm{Ca}_{10}\left(\mathrm{PO}_{4}\right)_{6} \mathrm{Cl}_{2},
\end{gathered}
$$

and the transverse ones reduce indicating to an increase of the covalent component of $\mathrm{Ca}_{(2)}-\mathrm{O}_{(3)}$ interaction in the series.

The substitution of $\mathrm{Ca}$ for $\mathrm{Cd}$ in the structures of chloro-, fluoro- and hydroxyapatite is accompanied by reduction of the longitudinal component of the interatomic force constants for phosphorus-oxygen bonds. The reason is the substitution causes the decrease of electronic density at $\mathrm{PO}_{4}$ tetrahedra which is to be accompanied by lowering the phonon frequencies.

$\mathrm{PO}_{4}$-tetrahedron is the main constituent of all phosphate apatites. In Table 9, we submit the calculated vibrational modes of isolated $\mathrm{PO}_{4}$-tetrahedron.

Modes $v_{3}$ and $v_{4}$ are threefold degenerate, mode $v_{2}$ is twofold degenerate, and $v_{1}$ is nondegenerate. The calculations showed that $\mathrm{P}-\mathrm{O}$ bond length reduces with the decrease of ionic charge of $\mathrm{PO}_{4}$-tetrahedron. Frequencies of $v_{1}$ and $v_{4}$ modes, which mainly correspond to the phosphorus-oxygen oscillations, reduce with the decrease of ionic charge of $\mathrm{PO}_{4}$-tetrahedron. Calculated vibration frequencies for isolated $\mathrm{PO}_{4}$-tetrahedron were not in so good agreement with the experimental analogs than the ones for the apatites. Especially large deviations of the calculation results from experimental values are established for the modes with lower frequencies ( $v_{2}$ and $v_{3}$ modes). Such 
errors are likely caused by the plane waves do not fit to describe phonon frequencies of isolated molecule and too large acoustic sum violation occurs (maybe local orbitals would give better results). The other reason can be that negative charged ion contains spurious self-interaction which influences calculated phonon frequencies.

\section{Conclusions}

Phonon densities of states, dielectric constants, the Born effective charges, interatomic force constants of the stoichiometric apatites $\mathrm{Me}_{10}\left(\mathrm{PO}_{4}\right)_{6} \mathrm{X}_{2}$, where $\mathrm{Me}=\mathrm{Ca}$ or $\mathrm{Cd}$ and $\mathrm{X}=\mathrm{F}, \mathrm{Cl}, \mathrm{Br}$, OH, were calculated in the framework of DFPT with the pseudopotential approach and plane wave basis sets. The phonon densities of states of all investigated apatites were proven to have similar structures which consist of four bands, consistently with previously reported phonon spectra of $\mathrm{Ca}_{10}\left(\mathrm{PO}_{4}\right)_{6} \mathrm{~F}_{2}$ and $\mathrm{Ca}_{10}\left(\mathrm{PO}_{4}\right)_{6}(\mathrm{OH})_{2}$. The phonon frequencies for the calcium apatites are well consistent with the experimental IR-absorption curves.

We have established the effects of evolution in spatial charge distributions, electron energy structures of valence bands and band gaps for apatites of the series $\mathrm{Me}_{10}\left(\mathrm{PO}_{4}\right)_{6} \mathrm{X}_{2}$, where $\mathrm{Me}=\mathrm{Ca}$ or $\mathrm{Cd}$ and $\mathrm{X}=\mathrm{F}, \mathrm{Cl}, \mathrm{Br}, \mathrm{OH}$. The band gaps in calcium apatites were correctly described in the framework of the density functional theory. In cadmium apatites the electronegatitvity of $c$-anion correlated with the band gap width, the decrease of $c$-anion electronegativity is accompanied with decrease of the band gap.

The lattice constants and bond lengths in apatites $\mathrm{Me}_{10}\left(\mathrm{PO}_{4}\right)_{6} \mathrm{X}_{2}$, where $\mathrm{Me}=\mathrm{Ca}$ or $\mathrm{Cd}$ and $\mathrm{X}=\mathrm{F}, \mathrm{Cl}, \mathrm{Br}$, OH were calculated in the framework of the density functional theory, and they are in a good concordance with the experimental observations. The high stability of $\mathrm{PO}_{4}$-anions with respect to substitution of column ions in the apatite structure was found, which means the small variation in volumes of $\mathrm{PO}_{4}$ tetrahedra.

The strength of $\mathrm{Ca}_{(2)}-\mathrm{X}$ bonds was established to increase in the series

$$
\begin{gathered}
\mathrm{Ca}_{10}\left(\mathrm{PO}_{4}\right)_{6} \mathrm{~F}_{2} \rightarrow \mathrm{Ca}_{10}\left(\mathrm{PO}_{4}\right)_{6}(\mathrm{OH})_{2} \rightarrow \\
\mathrm{Ca}_{10}\left(\mathrm{PO}_{4}\right)_{6} \mathrm{Cl}_{2} \rightarrow \mathrm{Ca}_{10}\left(\mathrm{PO}_{4}\right)_{6} \mathrm{Br}_{2} .
\end{gathered}
$$

We have calculated phon on dispersion curves for $\mathrm{Ca}_{10}\left(\mathrm{PO}_{4}\right)_{6} \mathrm{~F}_{2}$, and have shown that the speed of sound along the six-fold screw axis in $\mathrm{Ca}_{10}\left(\mathrm{PO}_{4}\right)_{6} \mathrm{~F}_{2}, \mathrm{Ca}_{10}\left(\mathrm{PO}_{4}\right)_{6} \mathrm{Cl}_{2}$, $\mathrm{Ca}_{10}\left(\mathrm{PO}_{4}\right)_{6}(\mathrm{OH})_{2}, \mathrm{Ca}_{10}\left(\mathrm{PO}_{4}\right)_{6} \mathrm{Br}_{2}$ was larger than that in the planes perpendicular to it.

Simulations of isolated $\mathrm{PO}_{4}$-tetrahedron with different ionic charges were performed. Within the DFT-LDA method the total densities of states, unit cell constants, band gaps, and the Bader effective charges of some elements in the apatite group materials were calculated.

The extent of $\varepsilon^{0}$ tensor anisotropy increases in series

$$
\begin{gathered}
\mathrm{Ca}_{10}\left(\mathrm{PO}_{4}\right)_{6} \mathrm{~F}_{2} \rightarrow \mathrm{Ca}_{10}\left(\mathrm{PO}_{4}\right)_{6}(\mathrm{OH})_{2} \rightarrow \\
\mathrm{Ca}_{10}\left(\mathrm{PO}_{4}\right)_{6} \mathrm{Cl}_{2} \rightarrow \mathrm{Ca}_{10}\left(\mathrm{PO}_{4}\right)_{6} \mathrm{Br}_{2} .
\end{gathered}
$$

For the calcium apatite $\varepsilon^{0}{ }_{x x}$ is greater than $\varepsilon_{z z^{0}}^{0}$ In addition, the extent of $\varepsilon^{0}$-tensors anisotropy is higher than the ones of $\varepsilon^{\infty}$.

\section{References}

1. J.C.Elliot, Studies in Inorganic Chemistry, Amsterdam, Elsevier, 234 (1994).

2. L.Calderin, M.J.Stott, J.Phys.Rev.B, 67, 134106 (2003).

3. N.Leroy, E.Bres, J.European Cells and Materials, 2, 36 (2001).

4. L.Calderin et al., J.Phys.Rev.B, 72, 224304 (2005).

5. M.Corno et al., J.Phys.Chem.Chem.Phys., 8, 2464 (2006).

6. A.Pedone et al., J.Mater.Chem., 17, 2061 (2007).

7. E.Balan et al., J.Physics and Chemistry of Minerals, 38, 111 (2011).

8. A.Slepko et al., J.Phys.Rev.B, 84, 134108-1 (2011).

9. X.Gonze, B.Amadon, J.Computer Physics Communications, 180, 2582 (2009).

10. C.Hartwigsen, S.Goedecker, J.Hutter, J.Phys. Rev. B, 58, 3641 (1998).

11. X.Gonze, J.Phys.Rev. B, 55, 10337 (1997).

12. X.Gonze, C.Lee, J.Phys.Rev.B, 55, 10355 (1997).

13. D.R.Hamann, X.Wu, K.M.Rabe et al., J.Phys. Rev. B, 71, 035117 (2005).

14. P.Wu, Y.Z.Zeng, C.M.Wang, J.Biomaterials, 25, 1123 (2004).

15. K.Matsunaga, A.Kuwabara, J.Phys.Rev.B, 75, 014102-1 (2007).

16. P.Rulis et al., J.Phys.Rev.B, 67, 155104 (2003).

17. V.Karbovskiy, A.Shpak, Apatites and Apatitelike Compounds, Kiev, Naukova Dumka (2010) [in Russian].

18. S.Baroni, R.Resta, J.Phys.Rev.B, 33, 7017 (1986). 